\title{
Н.О. Исмаил
}

Әл-Фараби атындағы Қазақ ұлттық университеті, Қазақстан, Алматы қ. e-mail: nurislamorazalyuly@gmail.com

\section{ҚАЙЫРЫМАЫАЫҚ ҚЫЗМЕТТЕГІ КОНФЕССИЯАЫҚ, ФАКТОРАЫ ТААААУ}

\begin{abstract}
Аіни қайырымдылық дәстүрлері қайырымдылық пайда болған кезден бастау алады. Барлық Аіндердің қасиетті мәтіндерінде мейірімділік істеріне ерекше орын беріледі. Бір жағынан, мұқтаж адамдарға көмек беру әртүрлі діндер мен діни қауымдастықтарда нұсқама немесе тікелей талап ретінде көрініс береді. Бұл мақаяаның басты мақсаты - мұсылмандар, христиандар (католиктер, православтар, оның ішінде ескіғұрыпшылдар, протестанттар) мен еврейлер сияқты Аіни конфессиялардың қайырымдылық және мейірімділік туралы көзқарастарын салыстырмалы түрде талдау. Қайырымдылық туралы жалпы белгілер мен айырмашылықтар көрсетіледі. Мысалы, иудаизмде тіпті кедейлер мен бақытсыздардың пайдасына тұрақты шегерімдер өлшемі - цлака белгіленген, оның мөлшері табыстың оннан бір бөлігін құрайды. Мұсылмандар арасында да осындай норма бар, сондай-ақ бұл - көптеген христиан қауымдастықтарына да тән құбылыс. Аіни аспектілер туралы өте көп айтуға болады, сондықтан әртүрлі діни ілімдерді ұстанатын түрлі табынушылықтардағы қайырымдылықтың бағытталуына әсер еткен сәттерге тоқталдық.

Ислам, православиелік немесе католиктік христиандық, протестантизм, иудаизм болсын, кез келген діни мәдениетте қайырымды істердің және мұқтаж адамдарға көмектесудің маңыздылығы туралы айтылады. Осыған орай қай дінде қайырымдылық жасаудың қандай факторларға сәйкес жүргізілетіні қарастырылған. Мақалада айтылғандардың ішінен дін әлемнің түрлі аймақтарында қайырымдылықтың дамуына елеулі із қалдырды деген қорытынды жасауға болады.

Түйін сөздер: қайырымдылық, Аіни қайырымдылық, мейірімділік, филантропия, ислам, салақа.
\end{abstract}

\author{
N.O. Ismail \\ Al-Farabi Kazakh National University, Kazakhstan, Almaty, \\ e-mail: nurislamorazalyuly@gmail.com
}

\section{Analysis of the confessional factor in charitable activities}

Traditions of religious charity are leading from the beginning, perhaps, from the very times when blissful charm appears as it is. In the sacred texts of all religions, matters of mercy have a special place. On the one hand, help those who need it, there is a prescription or direct demand in different religions and religious communities. The main purpose of this article is to make a comparative analysis of the ideas of charity in such religious as Islam, Christianity (catolics, righteous, including the antiquity) of history. General features and differences between views on charity in these confessions are deduced.

It was revealed that in Judaism there is a measure of permanent disbursements in favor of the poor and the uncommon - tzdaka, tenth part of the income. A similar norm is found both among Muslims and Christian communities. In any religious culture, be it to Islam, Orthodox or Catholic Christianity, Protestantism, Judaism speaks of the importance of charity and assistance to people in need. It is also presumed in what way the charity should be produced. From all of the above, it is possible to conclude that religion has imposed a serious imprint on the development of charity in different regions of the world.

Key words: charity, religious charity, mercy, philanthropy, Islam, sadaqah.

\section{Н.О. Исмаил}

Казахский национальный университет имени аль-Фараби, Казахстан, г. Алматы, e-mail: nurislamorazalyuly@gmail.com

\section{Анализ конфессионального фактора в благотворительной деятельности}

Традиции религиозной благотворительности ведут свое начало, пожалуй, с тех самых времен, когАа благотворительность появляется как таковая. В священных текстах всех религий делам милосердия отводится особое место. С одной стороны, помощь тем, кто в ней нуждается, есть предписание или прямое требование в различных религиях и религиозных сообществах. 
Основная цель данной статьи - сделать сравнительный анализ идей благотворительности и милосердия в таких религиозных конфессиях, как ислам, христианство (католики, православные, включая старообрядцев, протестанты) и иудаизм. Выводятся общие черты и различия между взглядами на благотворительность в данных конфессиях.

Было выявлено, что в иудаизме установлена мера постоянных отчислений в пользу бедных и несчастных - цдака, десятая часть дохода. Подобная норма имеется и у мусульман, $и$ умногих христианских общин. В мюбой религиозной культуре, будь то ислам, православное или католическое христианство, протестантизм, иудаизм говорится о важности благотворительных Аел и помощи нужАающимся Аюдям. Также предусмотрено, каким образом Аолжна производиться благотворительность. Из всего вышеописанного можно сАелать вывоА, что религия наложила серьезный отпечаток на развитие благотворительности в разных регионах мира.

Кмючевые слова: благотворительность, религиозная благотворительность, милосердие, филантропия, ислам, садака.

\section{Kiрicпе}

Ғасырлар бойы қызу талқыға салынып келе жатқан мұқтаж адамдарға көмектесуге деген ұмтылыс, сондай-ақ адамзат табиғатына деген мейірімнің мақсатты көрінісі сипатындағы қайырымдылық тақырыбы әртүрлі діндер мен дәстүрлерде сан рет талданады. Мейірімділікті өзге адамға көрсетілген практикалық көмек дегеннен гөрі оның азаптарына эмоционалды және сезімтал жауап десек дәлірек болады. Мейірімділік материалдық көмектен ғана емес, жақынның рухани қолдауынан да тұрады. Мейірімділік жоғарыда аталған қайырымдылық ic-әрекеттің негізінде жатыр, көбінесе қоғамда қайырымдылық құбылысы орын алуының себептерінің бірі ретінде көрінеді.

\section{Зерттеу мақсаты}

Қайырымдылық қызметтің конфессиялар арасындағы жіктеліп, жасалу жолдарын түсіндіру.

\section{Зерттеу әдістемесі мен әдістері}

Зерттеу екі бөлімнен тұрды: теориялық және әдіснамалық болып. Теориялық бөлімінде қайырымдылық пен мейірімділіктің түсінідіріліп кеткен конфессиялардағы негіздемелері түсіндірілді. Ал әдіснамалық аспектісінде әлемдегі әлеуметтік жұмыс субъектілері ретінде діни ұйымдардағы қайырымдылықтың орны мен маңызы талданды.

\section{Ұғымның анықтамасы}

Қайырымдылық бастапқыда діни және этикалық нормалармен байланысты болды. Діни қайырымдылық дәстүрлері қайырымдылық пайда болған кезден бастау алады. Барлық діндердің қасиетті мәтіндерінде мейірімділік істеріне ерекше орын беріледі. Басқа әлемдік діндер сияқты ислам діні де жоғары адамгершілік тұлғаны қалыптастыруға үлкен көңіл бөлетіні белгілі. Құран мен Сүннетте адамның өмірін туғаннан өлімге дейін қамтитын әртүрлі моральдық нормалар анықталған. Өзін-өзі тұрақты моральдық жетілдіру әрбір тура сенімдегі адамның міндетіне жүктеледі. Діни ілімге сәйкес, Алла өзі кең пейілді және мейірімді бола отырып, мұсылмандардан да осындай қасиеттерді көрсетуді талап етеді. Құранда қиын жағдайға тап болған адамға жанашырлық таныту туралы ғана емес, сонымен бірге оған шынайы риясыз көмек пен қолдау көрсету туралы айтылады. Пайғамбардың өсиеті бойынша жеңілген адамға, құлға адамгершілікпен қарау, ренішті кешіру, адам шын қиын жағдайға кезіккенде қарыз алудан бас тарту, сондай-ақ бақытсыздыққа ұшыраған адамға ғана емес, қайырымдылық жасауға ниет еткен кез келген адамға көмектесуге дайын болу мұсылман үшін сүннет амалдар саналады.

Исламның діни ілімдеріне сәйкес өзі кең пейілді және мейірімді Алла барлық мұсылмандардан көркем мінезді болуларын бірдей талап етеді. Хидистердің бірінде мейірімділіктің мәні келесідей анықталған: «Адам қайтыс болғаннан кейін аталған үш нәрседен басқа оның барлық дүниелік жақсы істерін жазу тоқтайды олар: тірі зекет, пайдалы білім және дұғада еске алатын ұрпақ».

Алланың алдында тең дәрежедегі мұсылмандар бір-біріне қамқорлық жасауы керек. Мейірімділікті жат санайтын адамның жаны шынайы өмір сүріп жатқан болып саналмайды. Шынайы мұсылмандардың жүректері мейірімділік пен жанашырлыққа толы болуы керек, аталғандар зекет, садақа және құлшылық 
ету сияқты игі істерден көрініс табады. Адал мұсылманның ең маңызды парызының көрінісі - Алланың берген нығметтері үшін ризашылық білдіру және шүкірлік ету. Инфакқайырымдылықты қайырымдылықтың ең жетілген формасы ретінде қарастыруға болады.

Мұсылмандық қайырымдылықтың негізгі формалары - зекет пен садақа. Әрбір мұсылман зекет төлеуі керек. Зекет араб тілінен аударғанда «рақым», «тазару», «дұрыстық», «өсу» деген мағына береді. Бұл белгілі бір жағдайларда мұқтаж адамдарға берілуі керек мүліктен бөлінген соманы білдіреді.

Зекет - исламдағы үшінші негізгі тіректің бірі: Алладан басқа тәңір жоқ және Мұхаммед (с.ғ.с) оның елшісі екендігіне куәлік ету, дұға ету, зекет төлеу, қажылық жасау және Рамазан айында ораза ұстау. Зекет «тазартады» және жинақталған байлықты пайдалануды күнәсіз етеді.

Зекет - мұқтаж мұсылмандардың пайдасына салынатын арнайы салық, оны төлем қабілетті әр мұсылман жылына бір рет ақшамен, алтынмен, күміспен, үй жануарларымен (ipi қара және ұсақ мал мен түйе), дәнді дақылдармен (бидай, арпа, сұлы, күріш, жүгері, бұршақ және т.б.), сауда тауарларымен, пайдалы қазбалармен және табылған қазынамен төлеуге міндетті. Мүліктің әр санаты үшін зекеттің нақты мөлшері белгіленген. Табылған қазына, соның ішінде алтын, күміс және асыл тастар ең маңызды сомаға - олардың құнына 20\% салық салынды. Белгіленген санаттардың әрқайсысында мүліктің белгілі бір түрлеріне зекет есептеу шарттары қосымша қарастырылған.

Зекет тек ауқатты адамдардан алынады және оларда мүліктің белгілі бір шекті мөлшер (нисаб) бар деп болжайды; табысы аз адамдар одан босатылады. Егер адам зекет төлеуді елемейтін болса, оған ең ауыр жазалар қаупі төнеді - ол дінді таптаушы болып саналады және тозақта мәңгі күйетін болады: «Аллаһтың берген мейірімін бөліспей, қызғанышқа бой алдырғандар, бұл олар үшін ең жақсы деп санамасын, Жоқ - бұл олар ең жаманы! Қиямет күні оларды өздері қызғанған нәрселерімен міндетті түрде кісенделеді; ал Аллаға аспан мен жердің мұрасы тиесілі; және Алла сенің не істеп жатқаныңды біледі» (Құран 3: 180). Жаза бұл өмірде зекет төлемегендерді де күтеді. Мұхаммед пайғамбар оларға: «Алланың сыйына үміттеніп, зекет берген адам оны алады. Ал кім оны төлеуден бас тартса, біз оны және оның мүлкінің жартысын Иеміздің жазасы ретінде алып кетеміз».
Алайда мұсылмандардың бәрі бірдей зекет төлеуге мәжбүр болған жоқ. Егер адам оған аталған соманы иеленуге мүмкіндік бермейтіндей борышкер болса, немесе қалыпты өмір сүру үшін минималды жағдайлары жоқ және оларды сатып алу үшін ғана ақша жинаса, онда ол кезде зекет төлеуге міндетті емес болып табылады.

Зекет барлық мұқтаж адамдарға емес, тек сегіз белгілі санатқа арналған. Демек, бірінші санат - мүлкі белгілі бір деңгейге жетпейтін кедейлер (мискин). Екінші санат - мұқтаждар (факир). Бұл кедейлерден де нашар жағдаймен ерекшеленетін қайыршылар, олар ештеңесі жоқ адамдар, сондай-ақ жасына немесе ауруына байланысты ақша таба алмайтындар. Үшінші санат - зекетпен байланысты адамдар (амиль), имам зекет жинау және тарату үшін тағайындаған адамдар. Төртінші санат жүректеріне жұбаныш қажет (муаллафату кулубихим) - бұрын басқа дінді ұстанған, содан кейін Исламды қабылдаған және моральдық және материалдық қолдауды қажет ететін адамдар. Алтыншы санат - шариғатпен рұқсат етілген қарыздары барлар (харим). Жетінші санат - өзін исламға (ахла сабилиллах) қызмет етуге арнаған адамдар. Сегізінші санат - өз Отанында бай ма, жоқ па, қарамастан, өз мүлкінен ажыратылған жолаушылар (ибн-уссабиль). Бұл жағдайда сапардың мақсаты шариғатқа қайшы келмеуі керек. Меншік иесі өзінің зекетін барлық категориялар арасында бөлуге құқылы, сонымен қатар ол бір категориямен шектелуі мүмкін (Висам, Закят, Значение и польза закята).

Зекеттік мүлікті мешіт, намаз бөлмелерін, құдықтар немесе жолдар салу, сабан сатып алу, марқұмның қарызын өтеу немесе байға беру үшін пайдалануға рұқсат етілмейді. Бірақ сіз кедейдің (факирдің) қарыздарын өтей аласыз, ал қарыз алушы осы кедейлерге уәкілетті болады.

Исламда зекет берілмейтін адамдар да нақты анықталған. Біріншіден, зекетті әкесіне, атасына, ұлына, немересі мен әйеліне беруге тыйым салынады. Екіншіден, әйелінің күйеуіне зекет беруге құқығы жоқ. Үшіншіден, өзі зекет беретін мүлкі бар адамға зекет беруге тыйым салынады, өйткені шариғат бойынша ол бай болып саналады. Төртіншіден, Муазға жолданған пайғамбардың сөздері негізінде бай мұсылмандар мен мұсылман емесадамдарғазекет беруге тыйым салынады: «Бай мұсылмандардан зекет алып, кедей мұсылмандарға бер».

Бірақ оларға пайғамбардың сөзіне сүйене отырып, садақа беруге болады: «кез келген 
діннің адамдарына зекет беріңдер». Бесіншіден, оған берілген зекетті тыйым салынған нәрсеге жұмсайтын адамға, сондай-ақ ерекше жағдайларды қоспағанда, намаз оқымайтын адамға. Егер адам біреуге зекет берсе және оны кедейлерге бергеніне сенімді бола отырып, кейін оның бай екенін, қараңғыда қателескенін немесе әкесі немесе баласы алғанын білсе, онда зекет берілген болып саналады. Өйткені оны адам мұқтаж деп санайтын адамға беру керек болды (факир).

Алланың атымен берілетін садақаның көптеген түрлері бар, оларды жалпылай «қайыр» деп атайды. Егер зекет мұсылмандар үшін міндетті салық болса, ал садақа - ерікті жәрдем, қайырсадақа, қолда бар нәрседен бөліп беру. Тек қана материалдық емес: «жақсы кеңес, азап көрушіні жұбату, жақсы жаңалық, мазасыздықтан арылу, жолдағы кедергілерді жою, науқастарға бару» сияқты амалдар да қайыр беру деп саналады.

Адал сенімдегі мұсылман өзіне тиесілі емес нәрсені құрбан етеді, өйткені ат-Тауба сүресінде «Алла сенушілерден оларға дайындаған жұмақтың орны үшін олардың өмірі мен мүлкін сатып алды» делінген. Әлсіздер мен кедейлерге көмек көрсету қоғамдағы үйлесімділік пен тәртіпті сақтайды, сондықтан осы әлемде де, өлімнен кейін де рақым көзі ретінде көрініс береді.

Жақсы істерді көмекке зәру жандарға ізгі жүрекпен және ешкімді жазғырмай жасау өте маңызды: «Артында реніш бар іс-әрекеттен қарағанда, жақсы сөз айту мен кешіру әлдеқайда абзалырақ амал болмақ. Алла ешнәрсеге мұқтаж емес, ол өте қамқор» (Құран 2: 263). Шын мұсылман үшін нағыз байлық материалдық емес, Аллаға апаратын жолдағы рухани байлық болып табылады. Бай да, кедей де өз тағдырына риза болып, мұқтаж адамдарға қолдарынан келген байлықты құрбан етеді: «Өз қаражатын (Аллаһтың атымен) жұмсайтын, мейлі олар әл-ауқатта болсын, кедейшілікте болсын, өзінен жағдайы төмен адамдарға мейірімділік танытады. Шындығында, Алла игі істер жасағандарды жақсы көреді» (Құран 3: 134).

Құран құрбандық шалушының өзі үшін ең құнды нәрсені беруі керек деп үйретеді: «Уа, сенушілер! Иеленген нәрсенің ең жақсысын және жер бетінде өсірген ізгілікті (Алланың атымен) жұмсаңыз және өзіңіз көзіңізді жұмып тұрып алатын, өзіңіз үшін де пайдасы аз нәрсені (Алланың атымен) беруге тырыспаңыз. Шындығында, Алла - ештеңеге мұқтаж емес, мақтауға лайық» (Кұран 2: 267). Ең құнды нәрсені құрбан ету - тақуалық пен Аллаға жақындаудың маңызды шарттарының бірі. Сонымен бірге тақуалықтың өзі иманның жетілу дәрежесі және Алланың мейірімі ретінде түсіндіріледі (Так кому же выплачивается закят?,2015).

Зекет жасырын түрде берілуі керек. Әйтпесе, алушыда ұят сезімі оянуы мүмкін, осылайша ол өз еңбегімен ақша табуға деген ұмтылысын жоғалтады. Өз кезегінде, беруші мақтанышқа бой алдыруы мүмкін. Егер қайырымдылық басқаларға үлгі бола алса, оларды жігерлендіріп, қайырымдылыққа бағыттаса, оның жария болуы да мүмкін. Сонымен қатар, Құранды талдаушылар зекет ашық, ал садақа жасырын түрде төленуі керек деп санайды: «егер сіз зекетті жария түрде берсеңіз, ол өте жақсы. Егер сіз оны кедейлерге берген кезде жасырсаңыз, бұл сіз үшін одан да жақсы» (Құран 2: 271). Осыған байланысты мешіттерде садақа тастары пайда болды, оларға берушілер мұқтаждарға ақша сала алады, ал кедейлер бұл ақшаны қажет болғанша алады.

Зекет пен садақаның қабылдануының маңызды шарты - қайырымдылық Алланың атымен жасалады. Мұқтаж адамдарға беруші ризашылық пен мақтауға үміттенбеуі керек. Керісінше, ол алушының шынайы ризашылығын сезінуі керек. Ол Алланың мейіріміне ғана үміт артуы керек (Құран 76: 8-11).

Вакф - исламдық қайырымдылықтың маңызды бөлігі. Вакф (араб тілінен аударғанда «ұстау») - мемлекет немесе жеке адам «діни немесе қайырымдылық» мақсаттар үшін берген немесе мұраға қалдырған жылжымалы және жылжымайтын мүлік (жер, үй, мал, зергерлік бұйымдар және т.б.). Ислам мемлекеттерінің көпшілігінде вакфқа салық салынбайды және иеліктен шығарылмайды. Вакфтан түскен табыс исламның позициясын нығайтуға, сондай-ақ кедейлерге көмекке жұмсалады» (Гогоберидзе, 2009). Вакф ұғымы Құранда жоқ болатын. Вакф алғаш рет VII-VIII ғасырларда пайда болды. Араб халифатында, содан кейін барлық мұсылман елдеріне таралды. Революцияға дейін вакф мешіттер, мектептер мен мұсылман қайырымдылықтары үшін негізгі күнкөріс құралы болды.

Ислам заңдарына негізделген заңды вакф оның негізін қалаушы берілген мүлікке қатысты барлық құқықтардан толықтай айрылды деп болжады. Сонымен қатар, вакфалеттің негізін қалаушының ұрпақтарына кірістің бір 
бөлігін алуға құқық беретін қарапайым вакф (вакфалет) бар. Вакфтардан түскен кірістердің шығынын сот (қази) немесе арнайы қамқоршы (назир) бақылайды. Вакф меншігін басқаруды менеджерлер - мутаваллия жүзеге асырды. Оларды вакфтың негізін қалаушы өзі ұсынып, қази мақұлдаған.

Жеке меншік иесінің өз мүлкін вакфқа айналдыруы, оны кез келген діни немесе қайырымдылық мекемесіне беруі мұндай мекемелер берік және жойылуға қабілетсіз болған жағдайда ғана мүмкін болды. Біріншіден, бұл мешіттер, медреселер, әулие қабірі - олар мұқтаждарға қаражат әкелуде қоғамдық делдалдар, байлар мен кедейлер арасындағы көпірдің бір түрі болды. Ауқатты адамдардың бұл мекемелерге жасаған қайырымдылықтары олар қайтыс болғаннан кейін де, кедейлерге қызмет етеді. Қазіргі Исламдық қайырымдылық зерттеушілерінің пікірінше, садақа берудің ең жақсы тәсілі вакфтар арқылы қайырымдылық жасау.

Орыс қайырымдылық дәстүрі өзінің сыртқы көрінісінде қайырымдылық қызметінде негізінен бір бағытқа бағытталды: «үлестіруге арналған қайырымдылық кедейлікті сүюді білдірді». Жеке қайырымдылық басым болды, соның арқасында ежелгі орыс меценаты «Христос-сүюші» өзінің рухани даму деңгейін көтеруді ойлады.

Заманауи шіркеу ұйымдары бұл тұжырымдамағаүшінсәл өзгешемән қосады. Шіркеулердің әлеуметтік қызмет етуі (немесе басқаша айтқанда, қайырымдылық, әлеуметтік қызмет) - бұл шіркеу бастамасымен, ұйымдастырумен, үйлестіруімен және қаржыландыруымен немесе шіркеудің көмегімен жүзеге асырылатын қызмет. Мұндай іс-шаралардың мақсаты мұқтаж жандарға көмек көрсету болып табылады, сонымен бірге олардың алдына мемлекеттің функцияларын қайталамау міндеті қойылады. Әлеуметтік қызмет етудің ең басты мақсаты руханилық: оның қатысушылары махаббатты үйренуге шақырылады, өйткені мейірімді қызмет адамға сүйіспеншілікті табуға көмектеседі, ал онымен бірге қатар жанқиярлық, момындық, шыдамдылық, кішіпейілділік және басқа да христиандық ізгіліктер бойға дариды». Бірінші анықтамадан көріп отырғанымыздай, қайырымдылық қызметі өзі оны жасаушылардың белгілі бір моральдық жетілуінің дәлелі ретінде көрініс бере отырып, зерттеушілерді, ең алдымен, оның материалдық нәтижелері, мақсаттылығы, мұқтаж жандарға көмек көрсетудің тиімділігі тұрғысынан қызықтырады. Қайырымдылық туралы діни-шіркеу көзқарасы қайырымдылық жасаушылар мен бенефициарлардың христиандық ізгіліктерге ие болу құндылығын, адамгершілік жағынан өзін-өзі жетілдіру үдерісін алға шығарады (Капустина, 2007).

Ярослав Муудрыйдың тұсында толықтай қалыптасқан орыс православие шіркеуі Киев-Печерский монастырінде де өзінің қайырымдылық орталығын құрды. Бұл монастырь мұқтаж жандарға деген мейірімділігімен танымал болды - мұнда құдайға табынушыларға арналған тегін қонақ үй, аурухана, кедейлер үшін ақысыз асхана болған. Алғашқы кезде шіркеу қайырымдылық қызметінің негізгі нысаны болды. Шіркеу меншігі кедейлердің меншігі деп жарияланды, ал діни қызметкерлер бұл мүлікті жағдайы нашарларға бөліп беруші қызметін атқарды. Шіркеудегі қайырымдылықтың артуына қайыр беруді «күнәлардан қорғану» деп түсіну де әсер етті. Бұл шіркеуді ұзақ мерзімге қайырымдылық қызметіндегі басты орынға айналдырды.

Православиелік шіркеуінің қайырымдылық тұжырымдамасына қайырымдылық қызмет түрлерін саралау тән болғанын байқауға болады, оның басты бағыттары ретінде келесілерді айтса болады: «қарттар мен жалғызбасты қарияларға арналған үйлерді қамтамасыз ету; ауруханаларды қамтамасыз ету; баспанасыздар мен кедейлерге көмектесу; мүгедектерге көмек»; балалар үйі мен орындарына көмек және ең бастысы діни қызметкерлерге көмек көрсету (Кузина, 2015).

Православтықтармен қатар католиктер мен протестантта да, христиандықтың түрлі салаларының өкілдері сияқты мейірімділік пен қайырымдылықты діни қызметтің маңызды бөлігі деп санайды, ал кедейлерге қамқорлық жасау бұл байлықты дұрыс пайдалану деп түсіндіріледі. Қайырымдылық оны жасаушы топқа қатысты таңдамалы, адал ниетті, құпия және ерікті болуы керек. Байлардың кедейлер алдындағы жауапкершілігі идеясының негізінде қайырымдылық әлеуметтік әділеттілікті қалпына келтіру жолында жүзеге асырылады. Қайырымдылық кез келген христиан өкілінің міндеті болып саналады, бірақ ең алдымен - бай және текті адамдардың жауапкершілігіндегі міндет. Қоғамның кедей өкілі байлар үшін құтқару құралы болып саналды. 
Православиелік қайырымдылықтың барлық мәні қайырымдылық туралы евангелиялық ілімнен бастау алады (Мат. 5: 7), «мүліктеріңізді сатыңыз және кедейлерге беріңіз») және жақынға деген христиандық өсиеттер (Мат. 22: 39). «Қайыр беру» сөзі кең және тар мағынада қолданылады (2 Қор. 9: 9).

Сонымен қатар, қайырымдылықтыңдінимәнмазмұны тәңірге жақындау: «Қайырымдылық жасаушы кедейлерге қарыз береді және ол (құдай) оның рақымы үшін сыйақы береді» (астарлы әңгіме. 19: 17). Тар мағынада бұл кедейлерге жасалатын қайырымдылық (Мат. 6: 2-4; LK. 11-41; Деян. 3: 2; 10: 2). Православие ілімі қайырымдылық іс-әрекеттің мақсаты ретінде христиандық сүйіспеншіліктің, жанашырлықтың, жақсылық беруші Құдайға (теозис) ұқсаудың, құтқарылу жолында өзінөзі жетілдірудің көрінісін анықтайды (Капустина, 2007). Мейірімділік, көмек беруші, қайырымдылық жасаушы үшін де емес, сонымен бірге қайырымды адам үшін де емес, тек құдай үшін, адамдарды адамгершілікке және жоғары руханиятқа жетелеу үшін ғана жүзеге асырылады. Қайыр бермеу - қорқынышты күнә: «Егер адам жақынын жек көрсе, ол - күнәһар; ал кедейлерге мейірімді адам - бақытты» (нақыл сөз. 14: 21). Мейірімділік өсиеті христиан дінінде ең маңызды саналады. «Қайырымдылық ізгіліктердің патшайымы», - деді Әулие Иоанн Златоуст (Полное собрание творений Святого Иоанна Златоуста, 1895-7906:323-542).

Ескі ғұрыпшылдар үшін жоғарыда айтылғанмен қатар үш сыйлық туралы ілім ерекше мәнге ие. Мәскеу көпестерінің әйгілі отбасынан шыққан В.П. Рябушинский өзінің «Мәскеу көпестері» естеліктерінде Иоанн Предтеч жайында ежелгі ескі ғұрыпшылдардың өлеңдерін келтірген: «Жаратқан Ие үш сыйлық жіберді. Алғашқы сыйлық - крест және дұға. Екінші сыйлық - махаббат пен қайырымдылық. Үшінші сыйлық - түнгі дұға. Төртінші кітап - оку кітабы» (Рябушинский, 2015). Екінші сыйлыққа - махаббат пен қайырымдылыққа келетін болсақ, оған қайырымдылық үйлері, ауруханалар, асханалар қызмет етті. Ескі ғұрыпшылдар байлықты күнә деп есептемейді, сондай-ақ кедейшілікке де құдайға ұнамсыз нәрсе деп қарамайды. Байлардың кедейлерден айырмашылығы, олар өз байлығын билеушісі болып табылады. Өздерін мәңгілік өмірге таңдаулы ретінде есептеген ескі дәстүршілер барлық мұқтаж адамдар қауымында көмек беру арқылы қалай болғанда да өз әлемдерін сақтап қалуға тырысты. Бірақ өз әлемдерінің сыртында да мейірімділік жасай отырып, ескі ғұрыпшылдар бұл әрекетті құдайдың мейірімі мен шынайы сенім үшін жасады (Керов, 2004:19-20).

Ескі ғұрыпшылдар діни этикасы көбінесе протестанттық этикамен салыстырылады, бірақ соңғысы айтарлықтай айырмашылықтарға ие. Протестанттық діни психология құдайдың еркіне бағынумен сипатталады, ол көбінесе таңдаулылардың қатарына жататынына сенімділікпен байланысты. Байлық әділдіктің және Құдайға ұнамды болудың дәлелі болды. Кез келген тәсілмен бай болуға деген ұмтылыс осыдан пайда болды. Кедейлік, өз кезегінде, Құдайға ұнамсыздықтың белгісі ретінде қабылданды. Уақыт өте келе (XVIII ғасырдан бастап) протестанттардың қайырымдылығы көмекке мұқтаж адамның жанын құтқару мүмкіндігі ретінде таныла бастады. Сондықтан қайырымдылық, ең алдымен, адамның рухани жандануына, оның өз-өзін табуына көмек ретінде қарастырылады. Адамды жабырқамау керек, оның дамуы мен өзін-өзі дамытуы үшін қажетті жағдайлар жасау керек. Қайырымдылықты бұлай түсіну америкалық протестантизмде танымал «ковенант» идеясымен - Құдай, адам және «адал» қауымдастығы арасындағы келісіммен байланысты. Құдайға ұнамды діншіл қоғам құру үшін барлық немесе қоғамның көп бөлігінің игілігін ескеру қажет болды (Туманов, 2010:17). «Адал» қоғамдастықтың барлық мүшелеріне құрмет көрсете отырып, протестанттар қайырымдылық, ең алдымен, қоғамның кез келгенінің күйреуіне жол бермеуі керек деп санайды. Протестанттар православие рухы мен орыс менталитетіне жақын жеке қайырымдылықты айыптады: жетім баланы туыстарының қамқорлығына алған кезде протестанттар шығындарды мемлекеттік өтеудің міндетті шарты деп санайды. Сондықтан қайырымдылық көмек көрсету үшін, әдетте, істің барлық жағдайларын мұқият зерттеуден өткізу керек болды. Осының арқасында алғашқы протестанттар үшін қайырымдылық қоғаммен қатар мемлекет те қатысатын әлеуметтік жұмыс түріне айналады.

Католиктер үшін қайырымдылық идеясы материалдық (аш адамды тамақтандыру, шөл- 
дегеннің шөлін қандыру, киімі жоқты киіндіру, үйіне жолаушыны кіргізу, науқастың жағдайын сұрау, тұтқындағы адамды жерлеу) және рухани (күнәһарды қабылдау, дінсіз адамды үйрету, қайғырушыны жұбату, күмәнданушыға жақсы кеңес беру, ренішті кешіру, тірі және қайтыс болған адамдар үшін дұға ету) игі істер арқылы құтқарылу мүмкіндігі туралы идеямен байланысты (Сулакшин, Бачурина, Вилисов, 2013:19-20).

Католиктік мейірімділіктің, қайырымдылықтың маңызды негізі - ортақ игілік идеясы және онымен байланысты ынтымақтастық пен субсидиарлық қағидалар. Оларға сәйкес, әр католик жақындарының әл-ауқатына ықпал етуі керек, олардың өміріне қатысып, көмектесетіндермен тең қарым-қатынас орнатуы керек. Сонымен қатар, католиктер арасындағы қайырымдылыққа деген көзқарас лайықты өмір сүру жағдайларына, еңбекке, тамақтануға, білім алуға және мәдениетке қол жеткізуге ажырамас құқықтары бар әр адамның Құдайдың қадірқасиетін қорғау қажеттілігі туралы идеяға негізделген.

Бес кітапта, пайғамбарлық әдебиетте және даналық әдебиетінде қоғамның барлық топтары үшін міндетті болып табылатын қайырымдылық туралы өсиет бірнеше рет қайталанады. Иудаизмнің 613 міндетті ережелерінің ішінде адам мен оның жақынының қарым-қатынасын реттейтін этикалық мицвот (мицвот БИН адам ле хаверо) бар. Киелі кітапта қайырымдылықты білдіретін арнайы термин жоқ, бірақ кедейлердің пайдасына қандай да бір салық салуды қарастыратын бірнеше заңдар бар (Лекет, шихеха у-феа; Трумот у-ма ' асрот; сенбі; мерейтойлық жыл).

Лекет, шихеха у-феа иесінен егіннің үш бөлігін кедейлер мен келімсектерге беруді талап етеді. Лекет - егін жинау кезінде құлаған масақтарды егін алқабында қалдыру талабы. Киелі кітаптағы ұқсас нұсқаулар жүзімнің кішкене түйіндерін жұлып алмауды және жерден құлаған жидектерді көтермеуді бұйырады. Шихеха ұмытылған бауды қайта алу үшін алқапқа оралуға библиялық тыйым салуды білдіреді. Сондай-ақ, ол егістіктің кішкентай жерлеріне және егін жинауды ұмытып кеткен бір немесе екі бақша ағаштарына таралады. Пеа өрістің шеттерін қысымсыз қалдыруды бұйырады. Кедейлер тең жағдайда болуы үшін, сондай-ақ далада қалған егінді жинау кезінде төбелеспеу үшін, масақтарды тек қана қолмен және қатаң түрде белгіленген уақытта жыртып алу керек.

Інжілге сәйкес, әр жетінші (сенбі) жылы жер буға қалдырылып, қарыздар кешірілуі керек еді. Талмуд сонымен қатар жүзімді кесуге немесе жинауға болмайтынын айтып кеткен. Жеті жылдық цикл мерейтойлық жылды аяқтайды. Кез келген сенбі жылына тән өсиеттерден басқа, мерейтойлық жылы жоғалған немесе сатылған жер учаскелерінің алғашқы иелеріне оралу және еврей құлдарының босатылуы орын алды.

Інжілге сәйкес, қайырымдылық - бұл Құдайдың атрибуты: «ием, сенің Құдайың жетім мен жесірге уд береді, шетелдікті жақсы көреді және оған нан мен киім береді» (Топбаш, 2004). Сондықтан Исайя пайғамбардың кітабында: «Наныңды аштармен бөлісіп, қаңғыбастарды үйге кіргіз; жалаңаш адамды көргенде оны киіндір ... және аштарыңа жаныңды беріп, азап шеккен адамның жанын тамақтандыр: сонда сенің нұрың қараңғылықта көтеріліп, қараңғылығың түс сияқты болады» (Ис. 58: 7, 10). Ораза ұстайтын күн емес, адам ашығып, панасыз қалған адамды тамақтандыратын күн Исайяның кітабында Құдайға ұнамды деп жарияланады.

Талмудта қайырымдылықты цедака сөзімен белгілейді. Бұл еврей тіліндегі цедектен шыққан - «әділеттілік» деген мағынаны береді. Цедакаға ақша беретін адам әділетті әрекет істейді. Бұл ең маңызды өсиеттердің бірі. Заң оқытушысы Асси цедаканың мәнін былайша анықтады: «Қайырымдылық маңыздылығы жағынан барлық басқа өсиеттермен тең» (Бава Батра, 96). Еврей заңы әділетсіздікті тек азғындық емес, сонымен қатар заңсыз деп санайды. Тарихи өткен заманда өзін-өзі басқаратын еврей қауымдары цедаканың мөлшерін мемлекет қазір салықтардың мөлшерін анықтаған сияқты белгіледі.

Таурат яһудилерге табыстарының үштен бірін кедейлерге үш жылда (Заңды қайталау 26: 12) және жыл сайын кірістерінің қосымша пайызын беруді тапсырады (Вайкра 19: 9-10). Жүздеген жылдар өткеннен кейін, ғибадатхана қиратылып, ғибадатханалар мен діни қызметкерлер мен левиттердің қажеттіліктері үшін жыл сайынғы қоры жойылғаннан кейін, Талмуд әр еврейге жылдық кірістің оннан бір бөлігін цедака ретінде беруді бұйырды (Миш-не-Тора, кедейлерге сыйлықтар туралы заңдар 7: 5). 
Талмуд цедаканың әртүрлі деңгейлері туралы айтады: «Цедаканың сегіз дәрежесі бар, олардың біреуі екіншісінен жоғары. Ең жоғарысы егер олар кедей еврейге сыйлық немесе несие беру кезінде немесе оны сіздің ісіңізге қосу арқылы немесе оған жұмыс табу арқылы көмектескенде - көмек сұрамау үшін қол ұшын беріңіз» (Мишне-Тора, Сыйлықтар туралы заңдар 7).

М. Зборовский мен Э. Герцог «Халықпен өмір» кітабында: «Қаладағы өмір цедакадан басталып, аяқталады. Бала дүниеге келгенде әкесі кедейлерге тарату үшін ақша береді. Жерлеу рәсімінде марқұмның туыстары зиратты су басып, қайыршыларға тиын таратып: «Цедака өлімнен құтқарады» деп ән айтады. Өмірдегі кез келген өзгеріс қайырымдылық қажеттілігін еске салады. Жақсы болсын, жаман болсын, біз тиынды сандыққа саламыз. Сенбіде шамдарды жақпас бұрын, иесі жәшіктердің біріне тиынды лақтырады. Балалар қызмет ету дәстүрімен тәрбиеленеді. Әкесі ұлын кедейлерге беруді үйретеді, бірақ оны ол үшін жасамайды. Мұқтаж адамдар дәстүрлі үйге барғанда балалардан қайырымдылық жасауды жиі сұрайды. Қайыр тілеу ым-ишарасы рефлекске айналады» (Zborowski, Herzog, 1952:247).

Талмуд мұғалімдері қайырымдылықпен кім айналысуы керек, оны кімнің пайдалануға құқығы бар және қайырымдылық көмектің мөлшері қандай екенін дәл анықтады. Кейіннен бұл көзқарастарды Маймонид «Мишна Тора»да «кедейлерге сыйлықтар туралы галахиялық идеялар» бөлімінде, содан кейін Яаков бен Ашер мен Йосеф Каро кодтады. Иудаизмнің діни заңы қайырымдылықты әркімнің міндеті деп анықтайды. Табысы өте қарапайым адам да мұқтаж жандарға өзінен гөрі көмектесуі керек. Егер біреу қайырымдылықтан бас тартса немесе оның қаражатына қарағанда аз қайырымдылық жасаса, оны сот мәжбүрлеуі мүмкін. Қайырымдылық алуда әйелдер ер адамдардан, туыстары - сырттан, жерлестер резидент еместерден гөрі басымдыққа ие. Бірақ егер адам шетелдік қалада қаражатсыз қалса, онда ол да қайырымдылық жасауға құқылы. Адам өзін асырау үшін тұрмыстық заттарды сатуға міндетті емес, сондықтан мұқтаж болған жағдайда ол да қайырымдылыққа сене алады.

Байлықтың оннан бір бөлігін қайырымдылыққа беру «орташа» қасиет деп саналады, ал жиырмасыншы немесе одан азын беру сараңдық болып саналады. Сонымен қатар, кедейленіп қалмас үшін және басқалардың қайырымдылығын пайдалануға мәжбүр болмау үшін, байлықтың бестен бір бөлігінен көбін жұмсамау керек. Кедей адамның психологиясын ескеру керек және бенефициар абыройсыздық деп қабылдануы мүмкін іс-әрекет жасамау маңызды. Сондықтан, қайырымдылықтың ең жақсы түрі - бұл беруші мен алушының бірбірін танымайтын түрі. Қайырымдылықты ұйымдастыруға келетін болсақ, Маймонидтің айтуынша, «еврейлер тұратын әр қалада олар қайырымдылық көсемдерін (габбаэи цедака), сенбі қарсаңында өз бауырластарынан ақша жинап, кедейлерге тарату керек асыл және адал адамдарды тағайындауға міндетті. Қайырымдылық қоры болмаған еврей қауымдастығын біз ешқашан көрмедік немесе естіген жоқпыз» (Yad, Khilhot matnot aniim 9: 1-3). Ақша жинауды кем дегенде екі ақсақал жүзеге асыруы керек және оларды таратуға кем дегенде үш адам қатысуы керек еді. Кедейлер қайырымдылық қорын басқаруда тіркелді, сондықтан үйден қайыр сұраған қайыршыларға үлкен сомалар берілмеді. Қайырымдылық қоры сондай-ақ тұтқындағылардың төлемін өтеуге және кедей келіншектерге қалыңмал сыйлауға қызмет етті. Әрбір қоғамда кедейлерге арналған тегін асхана болды. Әдетте, қайырымдылық мақсаттары үшін жиналған ақша донорлардың нұсқауына сәйкес жұмсалуы керек болатын. Қайырымдылықты қолдану заңды болса да, оған мұқтаж адамға жүгінетін адамда ұялатын ештеңе болмаса да, оны пайдаланбау үшін қолдан келгеннің бәрін жасау ұсынылған.

\section{Қорытынды}

Осылайша, ислам да, христиан дінінің барлық тармақтары мен иудаизм мейірімділік пен қайырымдылықты жоғары бағалады, бірақ оны түсіну мен іс жүзінде жүзеге асыруда айтарлықтай айырмашылықтар болды. Кез келген мемлекет діни бірлестіктердің әлеуметтік бағдарланған қызметін дамытуға мүдделі, оларды әлеуметтік жұмыс, рухани-адамгершілік тәрбие және құқық бұзушылықтардың, маскүнемдіктің, нашақорлықтың алдын алу саласындағы бірлескен жобаларды іске асыруға тартады, бұл өз кезегінде саяси және әлеуметтік тұрақтылықты нығайтуға, сонымен бірге конфессияаралық бейбітшілікті қолдауға ықпал етеді. 


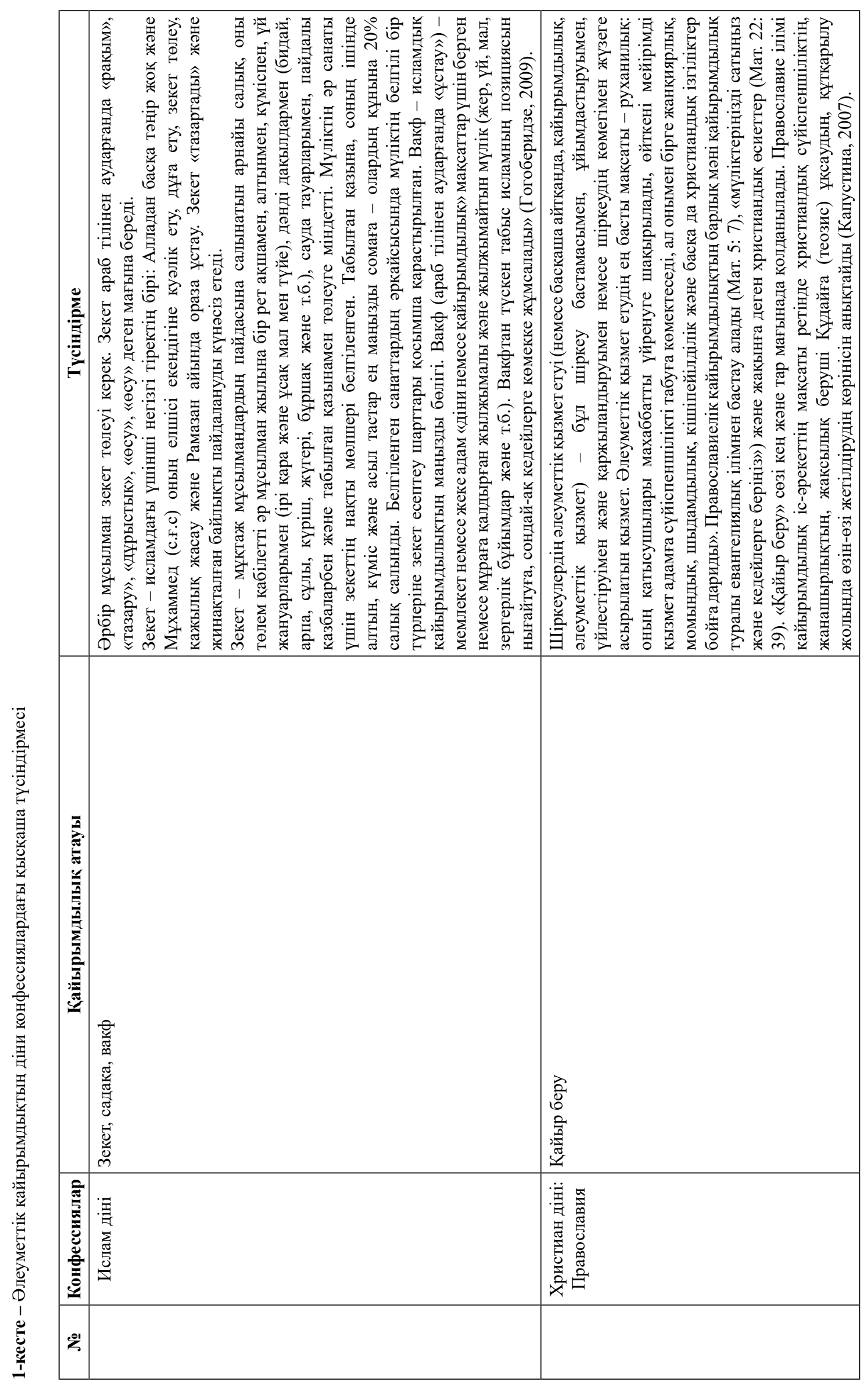




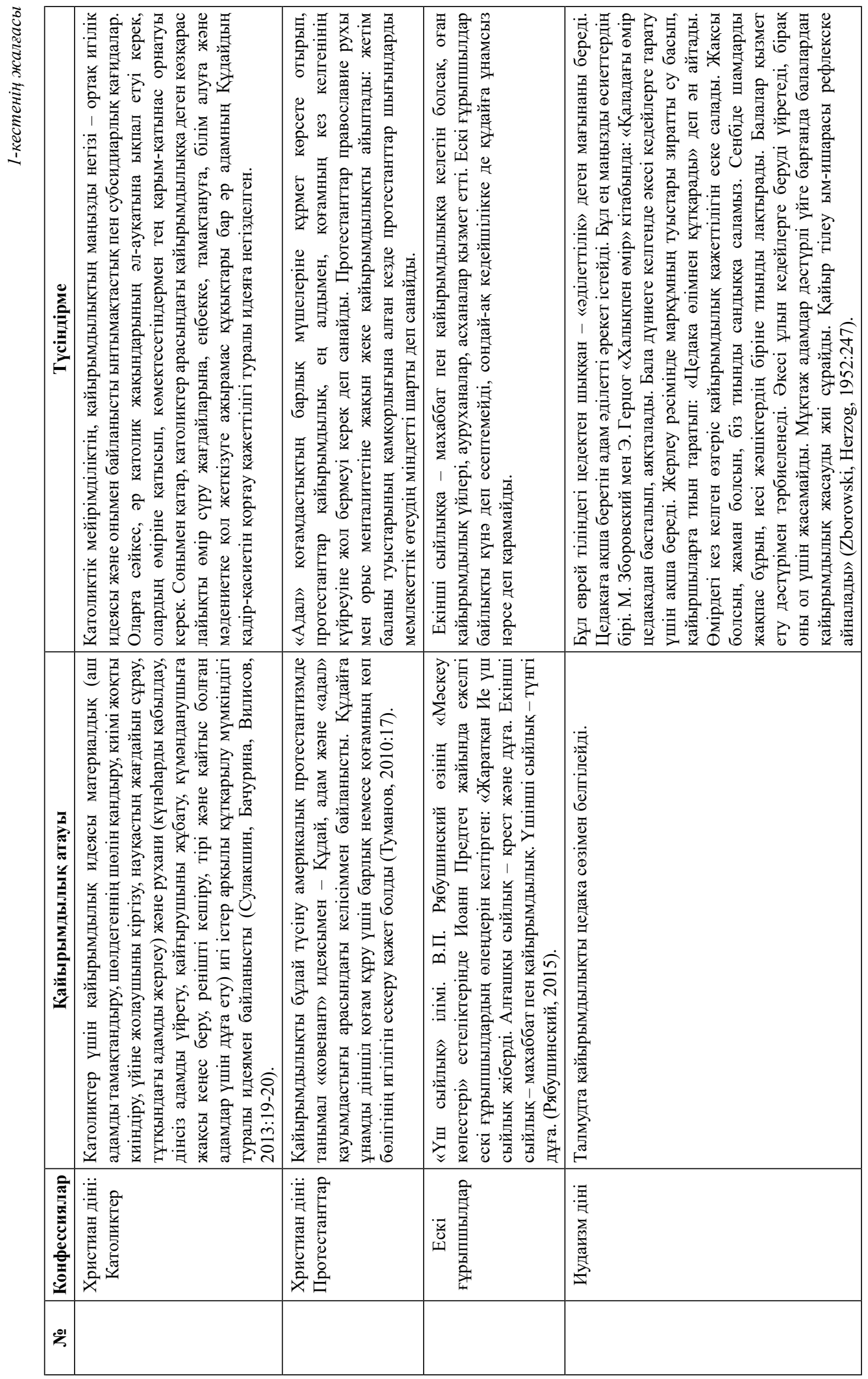




\section{Әдебиеттер}

Артемьев А.И. Дінтану. - Алматы: «Бастау», 2010. - 569 с.

Динур Б.У. Еврейская история. Ее особенности и непревзойденность // Век. - Рига, 2009. - № 2. - С. 112-115.

Висам Бардвил. Закят [Электронный ресурс]. URL: http://islam-book.info/zakon-obryadi/za kyat-osobiy-nalog/ (дата обращения: 16.11.2015).

Гогоберидзе Г.М. Исламский толковый словарь. - Ростов н/Д.: Феникс, 2009. - 266 с.

Значение и польза закята [Электронный ресурс] / Islamdag.kz: ислам. образоват. портал. URL: http://islamdag.kz/ verouchenie/2625 (дата обращения: 16.11.2015).

Кузина О. Беседа в руководителем Епархиального отдела по благотворительности и социальному служению в Балашовской епархии св. Сергием (Киреевым) [Электронный ресурс] // Балашовская епархия Саратовской митрополии Русской Православной Церкви (Московский Патриархат): [сайт]. URL: http://www.balashovblag.ru/index.php/2011-12- 23-0836-26/2012-01-19-07-55-17/1070-2012-06-01- 05-59-42.html (дата обращения: 08.11.2015).

Капустина А.М. Православно-христианская традиция благотворительности в России: философско-религиоведческий анализ: автореф. дис. ... канд. филос. наук. - Белгород, 2007.

Керов В.В. Конфессионально-этические факторы старообрядческого предпринимательства в России в конце XVII-XIX вв.: автореф. дис. ... д-ра ист. наук. - М., 2004. - С. 19-20.

Полное собрание творений Святого Иоанна Златоуста: в 12 т. - СПб.: Изд. С.-Петерб. Духовной Академии, 1895-1906.

Рябушинский В.П. Купечество московское [Электронный ресурc]. URL: http://1aya.ru/paper/art259004.php (дата обращения: 08.11.2015).

Туманов М.А. Роль религиозно-этических принципов кальвинизма в повседневной жизни американской колонии Новый Плимут в первой половине XVII в.: автореф. дис. ... канд. ист. наук. - М., 2010.

Так кому же выплачивается закят? [Электронный ресурс] // АССАЛАМ: духовно-просветительская газета. 2015. 15 авг. URL: http://assalam. ru/content/story/2526 (дата обращения: 16.11.2015).

Топбаш О.Н. Благотворительность. Служение. - Стамбул, 2004; - М.: Изд. группа «Сад», 2007.

Сулакшин С.С., Бачурина Д.В., Вилисов М.В. [и др.]. Благотворительность в России и государственная политика: моногр. - М.: Науч. эксперт, 2013. - С. 19-20.

Zborowski M., Herzog E. Life is with People: The Jewish Little-town in Eastern Europe. - N.Y.: International Universities Press, 1952. - P. 247.

\section{References}

Artem'ev A.I. (2010) Dintanu [Religious studies]. Almaty: "Bastau", 569 p.

Dinur B.U. (2009) Evreiskaya istoriya. Ee osobennosti i neprerivnost [Jewish history. Its features and consistency]. Vek, Riga, No 2, pp. 112-115.

Gogoberidze G.M. (2009) Islamskij tolkovyj slovar' [Islamic Dictionary]. Rostov n/D.: Phoenix, p. 266.

Kapustina A.M. (2007) Pravoslavno-hristianskaja tradicija blagotvoritel'nosti v Rossii: filosofsko-religiovedcheskij analiz [The Orthodox Christian Tradition of Charity in Russia: Philosophical and Religious Analysis]. Belgorod.

Kerov V.V. (2004) Konfessional'no-jeticheskie faktory staroobrjadcheskogo predprinimatel'stva v Rossii v konce XVII-XIX vv. [The confessional and ethical factors of the old age group in Russia in the late 17th - 19th centuries]. M., pp. 19-20.

Kuzina O. (08.11.2015). Beseda v rukovoditelem Eparhial'no- go otdela po blagotvoritel'nosti i social'nomu slu- zheniju v Balashovskoj eparhii sv. Sergiem (Kire- evym) [A conversation with the head of the Diocesan Department for charity and social service in the Balashov Eparchy of St. Sergiyev (Kiriev)] [Electronic resource]. URL: http://www. balashovblag.ru/index.php/201112-23-08-36-26/2012- 01-19-07-55-17/1070-2012-06-01-05-59-42.html.

Polnoe sobranie tvorenij Svjatogo Ioanna Zlatousta: v 12 t. (1895-1906) [Complete collection of the works of St. John Zlatoust: in 12 volumes]. St. Petersburg: Publishing house. Peterb. Spiritual Academ.

Rjabushinskij V.P. (08.11.2015). [Merchant Moscow]. [Electronic resource]. URL: http://1aya.ru/paper/art259004.php.

Sulakshin S.S., Bachurina D.V., Vilisov M.V. (2013) [Charity in Russia and state policy]. M.: Science. ekspert, pp.19-20.

Tak komu zhe vyplachivaetsja zakjat? [So who gets paid zakyat?]. [Jelektronnyj resurs]. (16.11.2015) // ASSALAM: duhovnoprosvetitel'skaja gazeta. 2015. 15 avg. URL: http://assalam. ru/content/story/2526

Topbash O.N. (2007) Blagotvoritel'nost'. Sluzhenie. Ctambul, 2004 [Charity. Service. Istanbul, 2004]. M.: Ed. group "Sad".

Tumanov M.A. (2010) Rol' religiozno-jeticheskih principov kal'vinizma v povsednevnoj zhizni amerikanskoj kolonii Novyj Plimut v pervoj polovine XVII v. [The role of the religious and ethical principles of Calvinism in the daily life of the American colony New Plymouth in the first half of the 17th century]. M., $17 \mathrm{p}$.

Visam Bardvil. (16.11.2015) Zakjat [Zakyat]. [Electronic resource]. URL: http://islam-book.info/zakon-obryadi/zakyat-oso biy-nalog/.

Zborowski M., Herzog E. (1952) Life is with People: The Jewish Little-town in Eastern Europe. N.Y.: International Universities Press, $247 \mathrm{p}$.

Znachenie i pol'za zakjata [The value and use of the zakyat]. (16.11.2015). [Electronic resource] / Islamdag.ru: islam.URL: http://islamdag.ru/verouchenie/2625. 